Global Conferences Series:

Social Sciences, Education and Humanities (GCSSSEH), Volume 6, 2020

International Conference Fakultas Tarbiyah dan Keguruan Universitas Islam Negeri Imam Bonjol Padang (ICFTKUINIBP) 2020

DOI: https://doi.org/10.32698/icftk418

\title{
Free Learning: Study of Humanistic Theory in Islamic Religious Education
}

\section{Merdeka Belajar: Telaah tentang Teori Humanistik pada Pendidikan Agama Islam)}

\author{
Gusmaneli $^{\mathrm{a}}$, Khadijah ${ }^{\mathrm{a}}$, Radhiatul Hasnah ${ }^{\mathrm{a}}$ \\ ${ }^{a}$ Universitas Islam Negeri Imam Bonjol, Padang, Indonesia \\ E-mail: gusmanelidarwin@gmail.com
}

\begin{abstract}
This article aims to describe the humanistic theory and its analysis of Islamic Religious Education. The method of writing this article uses descriptive analytic method, which means that it describes and simultaneously provides an analysis of the problems discussed. From the analysis, the writer suggests that: Humanistic theory aims to humanize humans. The learning process is considered effective when students understand themselves and their surroundings. Students in a series of learning should strive to be able to actualize themselves as best as possible, for that PAI learning in a humanistic paradigm, teachers and students are required to be able to develop their potential to the maximum so as to create an independent learning atmosphere in accordance with the characteristics and development of students. In accordance with the objectives of Islamic Religious Education, the expected education is able to make students become whole individuals both according to the human perspective in concept and as servants of Allah who are made as caliphs on earth so that they are able to apply the knowledge gained to achieve progress both for themselves and for themselves. environment in the future.
\end{abstract}

Keywords: Humanistic, islamic education

\section{PENDAHULUAN}

Merdeka Belajar yang dicanangkan oleh Mendikbud Nadiem Makarim dapat dihubungkan dengan memahami dan mengubah sudut pandang pendidikan dengan teori Humanistik dalan hal ini perlu dilakukan perubahan dalam pendidikan. Pendidikan merupakan rangkaian humanisasi berasal dari pemikiran faham humanistik. Merdeka belajar relevan dengan arti fundamental faham humanistik sebagai pengedukasian manusia. Sistem edukasi Islam yang disusun di atas fondasi nilai-nilai kemanusiaan dari awal kelahirannya sejalan dengan esensi Islam sebagai agama yang humanistik.

Islam memposisikan aspek kemanusiaan sebagai arah pendidikannya. Edukasi dan proses pembelajaran di bangku sekolah dipandang kurang demokratis hal ini disebabkan minimnya wadah bagi peserta didik untuk mengembangkan daya imajinasi dan kreasi dengan sudut pandang mereka. Padahal, daya kreasi dan kompetensi kritis dalam berpikir adalah modal berharga bagi peserta didik supaya dapat mengatasi tantangan dan lebih kompetitif dimasa mendatang.

Belajar merupakan suatu aktivitas psikis yang dilakukan oleh seseorang sehingga terjadi perubahan pola pikir dan perilaku yang diakibatkan oleh belajar tersebut. Belajar juga dapat diartikan sebagai kegiatan yang dapat mengubah struktur pengetahuan lama hingga terbentuk struktur pengetahuan baru. Belajar merupakan proses dasar dari perkembangan hidup anak didik. Dengan belajar anak didik melakukan perubahan-perubahan kualitatif, sehingga tingkah lakunya berkembang Agus (2013)

Belajar adalah suatu proses perubahan pada diri seseorang yakni perubahan tingkah laku sebagai hasil interaksi dengan lingkungannya. Perubahan tersebut dapat ditunjukkan dalam berbagai bentuk, seperti perubahan pengetahuan, sikap dan tingkah laku, keterampilan, kecakapannya, kemampuannya, daya reaksinya dan daya penerimaanya. Beberapa pendapat yang berhubungan dengan belajar diantaranya: perubahan struktur mental individu menunjukkan perubahan perilaku (learning is a change in a person's mental structure that provides the capacity to demonstrate change in behaviour) Syarifuddin, (2011).

Copyright (2020, the Authors. Published by Redwhite Press.

Page | 168

This is an open access article under the CC BY-NC license

(http://creativecommons.org/licenses/by-nc/4.0). 
Hal senada juga disebutkan bahwa belajar merupakan kewajiban bagi setiap muslim dan muslimah dalam rangka memperoleh ilmu pengetahuan sehingga derajat hidupnya meningkat. Adapun salah satu firman Allah Swt yang menjelaskan hal tersebut ialah dalam surat al-Mujadalah ayat 11. Menurut Nidawati, (2013) Belajar merupakan kewajiban bagi setiap muslim dan muslimah dalam rangka memperoleh ilmu pengetahuan sehingga derajat hidupnya meningkat. Belajar juga merupakan suatu perubahan dalam tingkah laku menuju perubahan tingkah laku yang baik, dimana perubahan tersebut terjadi melalui latihan atau pengalaman.

Perubahan tingkah laku tersebut harus relatif mantap yang merupakan akhir daripada suatu periode waktu yang cukup panjang. Tingkah laku yang mengalami perubahan karena belajar tersebut menyangkut berbagai aspek kepribadian baik fisik maupun psikis, seperti perubahan dalam pengertian, pemecahan suatu masalah/berfikir, keterampilan, kecakapan ataupun sikap Sudarwan Darnim, (2011). Tujuan belajar bukanlah mencari rezeki di dunia semata, tetapi untuk sampai kepada hakikat, memperkuat akhlak, artinya mencari atau mencapai ilmu/belajar yang sebenarnya dan akhlak yang sempurna Zuhairini, (2009). Belajar dan pembelajaran merupakan aktivitas utama dalam proses pendidikan. Pendidikan merupakan sebuah usaha sadar dan terencana untuk mewujudkan suasana belajar dan proses pembelajaran, agar peserta didik secara aktif mengembangkan potensi dirinya sehingga memiliki kekuatan spiritual keagamaan, pengendalian diri, kepribadian, kecerdasan, akhlak mulia, serta keterampilan yang diperlukan baik untuk diri peserta didik itu sendiri maupun untuk masyarakat, bangsa dan Negara.

Menurut Hanafy, (2014). Pendidikan yang humanistik memandang manusia sebagai makhluk ciptaan tuhan dengan fitrah-fitrah tertentu untuk dikembangkan secara optimal. Hal senada juga di unggapakan Baharuddin, ( 2009) Selain itu pendidikan islam (humanistik) adalah pendidikan yang mampu memperkenalkan apresiasinya yang tinggi kepada manusia sebagai makhluk Allah yang mulia dan bebas serta dalam batas-batas eksistensinya yang hakiki dan tentu sebagai khalifatullah.

Hal yang senada juga diunggapkan Haryu, (2006), bahwa: pendidikan diharapkan mampu menjadikan peserta didik sebagai pelaku pendidikan sehingga mampu membentuk pribadi yang unggul, pribadi utuh dan pribadi yang memiliki ketangguhan dan kesiapan dalam menghadapi era persaingan global dan nilai- nilai daya saing yang tinggi dan kritis terhadap berbagai permasalahan.

Berdasarkan beberapa pendapat yang dikemukan di atas dipahami bahwa: pendidikan yang diharapkan mampu menjadikan peserta didik untuk menjadi pribadi yang utuh baik menurut pandangan manusia secara konsep yang maupun sebagai hamba Allah yang dijadikan sebagai khalifah dibumi sehingga mampu mengaplikasikan ilmu yang di dapat dalam proses belajar untuk mencapai kemajuan baik terhadap dirinya sendiri maupun terhadap lingkungannya.

\section{METODE}

Penulisan artikel ini mengunakan metode deskriptif analitik artinya dalam mendeskripsikan dan sekaligus memberikan analisis terhadap permasalahan yang dibahas dalam Teori Humanistik dan Pendidikan Agama Islam.

\section{PEMBAHASAN}

\section{Teori Belajar Humanistik}

Teori humanistik menekankan pentingnya "isi" dari proses belajar, dalam kenyataannya teori ini lebih banyak berbicara tentang pendidikan dan proses belajar dalam bentuk yang paling ideal. Dengan kata lain, teori ini lebih tertarik pada ide belajar dalam bentuknya yang paling ideal dari pada belajar apa adanya, seperti apa yang bisa kita amati dalam dunia keseharian. Wajar jika teori ini sangat bersifat elektrik. Teori apa pun dapat dimanfaatkan asal tujuan untuk "memanusiakan manusia" (mencapai aktualisasi diri dan sebagainya itu) dapat tercapai Uno, (2006: 13). Dalam hal ini juga menjelaskan bahwa dalam teori humanistik, yang menjadi tujuan belajar adalah memanusiakan manusia. Jadi peserta didik dalam proses belajarnya diharapkan mampu berusaha mencapai aktualisasi diri dengan sebaik-baiknya.

Proses belajar baru dianggap berhasil, jika anak didik mampu memahami dirinya sendiri dan lingkungannya subini, (2012: 138-139). Secara konsep manusia yang identitas insaninya sebagai subjek berkesadaran perlu dibela dan ditegakkan lewat sistem dan model pendidikan yang bersifat "bebas dan egaliter". Tantangan dunia pendidikan ke depan adalah mewujudkan proses demokratisasi belajar.

Suatu proses pendemokrasian yang mencerminkan bahwa belajar adalah atas prakarsa anak. Demokrasi belajar berisi pengakuan hak anak untuk melakukan tindakan belajar sesuai dengan kebutuhan dan karakteristiknya. Salah satu prasyarat terwujudnya masyarakat belajar yang demokratis adalah adanya 
pengemasan pembelajaran yang beragam dengan cara menghapuskan penyeragaman kurikulum, strategi pembelajaran, bahan ajar, dan evaluasi belajar. Untuk mengembangkan agar manusia menjadi matang tidak cukup bila ia hanya dilatih, tetapi juga harus dididik. Peserta didik diharapkan dididik untuk realis, mengakui kehidupan yang multidimensional, tidak seragam dan diajak menghayati kebinekaan yang saling melengkapi. Sedangkan pada pelatihan, yang terutama dibentuk adalah tingkah laku lahiriah. Berbeda dengan pendidikan, yang dibentuk adalah disposisi mental dan emosional.

Mendidik bukan berarti sekedar menjadikan anak terampil secara praktis terhadap lingkungannya. Mendidik juga berarti membantu anak untuk menjadi dirinya dan peka terhadap lingkungannya. Pengaturan lingkungan belajar sangat diperlukan agar anak mampu melakukan control terhadap pemenuhan kebutuhan emosionalnya. Menurut Ni Nyoman (2018). Lingkungan belajar yang demokratis memberi kebebasan kepada anak untuk melakukan pilihan - pilihan tindakan belajar dan akan mendorong anak untuk terlibat secara fisik, emosional, dan mental dalam proses belajar, sehingga akan dapat memunculkan kegiatan kegiatan yang kreatif-produktif. Salah satu cara yang dilakukan pendidik untuk mendorong peserta didik agar terlibat secara fisik, emosional dan mental dengan menggunakan teori belajar humanistik dalam proses pembelajaran. Adapun tokoh - tokoh humanistik yang tergabung di dalamnya adalah:

\section{Teori belajar humanistik Abraham Maslow}

Abraham Maslow lahir di New York pada 1908, ia dikenal dengan jasanya membidangi lahirnya pandangan pengaktualisasian diri. Ia wafat pada 1970 di California, Amerika. Jhon (2009:201) Menurut Maslow dalam perspektif humanistik (humanistic perspective) menuntut potensi peserta didik dalam proses tumbuh kembang, kebebasan menemukan jalan hidupnya. Humanistik menganggap peserta didik sebagai subjek yang merdeka guna menetapkan tujuan hidup dirinya. Peserta didik dituntun agar memiliki sifat tanggung jawab terhadap kehidupannya dan orang di sekitarnya. Arbayah (2009:201)

Pembelajaran humanistik menaruh perhatian bahwa pembelajaran yang pokok yaitu upaya membangun komunikasi dan hubungan individu dengan individu maupun individu dengan kelompok. Edukasi bukan semata-mata memindah khazanah pengetahuan, menempa kecakapan berbahasa para peserta didik, tapi sebagai wujud pertolongan supaya peserta didik mampu mengaktualisasikan dirinya relevan dengan tujuan pendidikan.

Edukasi yang berhasil pada intinya adalah kecakapan menghadirkan makna antara pendidik dengan peserta didik sehingga dapat mencapai tujuan menjadi manusia yang unggul dan bijaksana. Maksudnya ialah menuntun peserta didik bahwa mereka butuh pendidikan karakter. Pendidik memfasilitasi peserta didik menggali, mengembangkan dan menerapkan kecakapan-kecakapan yang mereka punya supaya mampu memaksimalkan potensinya. Maslow terkenal sebagai bapak aliran psikologi humanistik, ia yakin bahwa manusia berperilaku guna mengenal dan mengapresiasi dirinya sebaik- baiknya. Teori yang termasyhur hingga saat ini yaitu teori hirarki kebutuhan.

Menurutnya manusia terdorong guna mencukupi kebutuhannya. Kebutuhan - kebutuhan itu mempunyai level, dari yang paling dasar (sederhana) hingga level tertinggi. Dalam teori psikologinya yaitu semakin besar kebutuhan maka pencapaian yang dipunyai oleh individu semakin sungguh-sungguh menggeluti sesuatu. Perspektif ini diasosiasikan secara dekat dengan keyakinan Abraham Maslow bahwa kebutuhan dasar tertentu harus dipenuhi sebelum kebutuhan yang lebih tinggi dapat dipuaskan.

Menurut hierarki kebutuhan Maslow, pemuasan kebutuhan seseorang dimulai dari yang terendah yaitu: 1) Kebutuhan fisiologis (Physiological) yaitu Kebutuhan yang bersifat dasar. Contoh kebutuhan akan udara, makanan, minuman dan sebagainya. 2) Rasa Aman (Safety,) Berhubungan dengan jaminan keamanan, stabilitas, perlindungan, struktur, keteraturan, situasi yang bisa diperkirakan, bebas dari rasa takut, cemas dan sebagainya. 3) Rasa memiliki dan dimiliki (Belonging-love), Kebutuhan mempunyai hubungan yang hangat dan akrab. Mencintai dan dicintai. Setia kawan dan butuh kesetiakawanan. Ingin mempunyai kelompok sendiri. Ingin punya "akar" dalam masyarakat. 4) Harga diri (Self esteem), Kebutuhan akan kekuatan, penguasaan, kompetensi, percaya diri, dan kemandirian. Kebutuhan akan penghargaan dari orang lain, status, ketenaran, dominasi, kebanggaan, dianggap penting dan apresiasi dari orang lain. 5) Aktualisasi diri (self actualization) Kebutuhan akan aktualisasi diri. Untuk lebih jelasnya dapat dilihat pada gambar di bawah ini: 


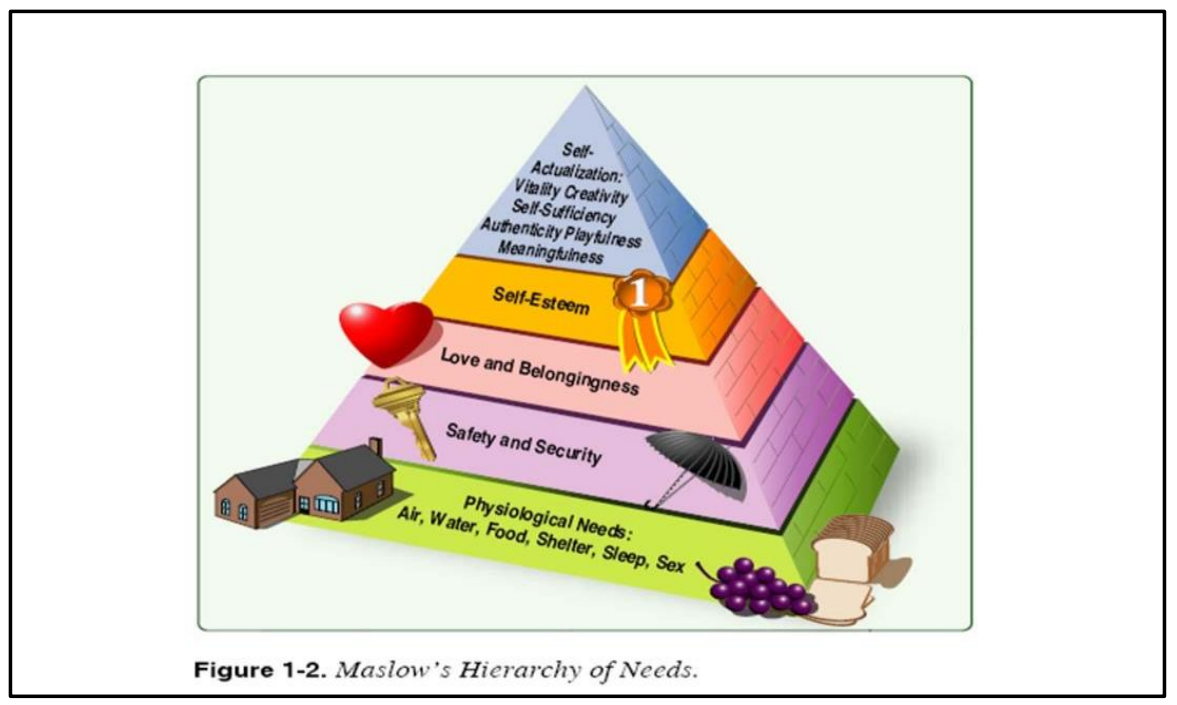

Sumber: https://whatmaster.com/maslow-pyramid/

Grafik 1. Pyramid Maslow

\section{Teori Belajar Humanistik Carl Rogers}

Carl Rogers Carl Ransom Rogers dilahirkan pada tahun 1902 di Oak Park, Illinois, Pada tahun 1928 ia memperoleh gelar Master di bidang psikologi dari Columbia University dan kemudian memperoleh gelar Ph.D di dibidang psikologi klinis pada tahun 1931 dan wafat pada tahun 1987 di Lajolla, California. Salah satu ranah ketika ide Rogers masih terus memiliki banyak pengaruh adalah dalam peraihan tujuan. Menurut (Jess, 2009: 33), menetapkan dan meraih tujuan adalah suatu cara manusia untuk mengatur kehidupannya supaya dapat memberikan hasil yang diinginkan dan menambah arti pada kegiatan sehari-hari. Menetapkan tujuan merupakan hal yang mudah, namun menetapkan tujuan yang tepat dapat menjadi lebih sulit daripada kelihatannya. Menurut Rogers dalam Jamil Suprihati ningrum, ada dua tipe belajar, yaitu kognitif (kebermaknaan) dan eksperimental (pengalaman).

Menurut Jamil, (2013: 31-32) Guru memberikan makna (kognitif) bahwa tidak membuang sampah sembarangan dapat mencegah terjadinya banjir. Jadi, guru perlu menghubungkan pengetahuam akademik ke dalam pengetahuan bermakna. Sementara experimental learning melibatkan peserta didik secara personal, berinisiatif, termasuk penilaian terhadap diri sendiri (self assessment). Sedangkan menurut Carl Rogers dalam teori belajar bebasnya, menyatakan bahwa tidak ada paksaan atau tekanan dalam belajar. Menurut Uci, (2013:126) Guru tidak bembuat rencana dalam pembelajaran untuk peserta didik, tidak memberikan kritik atau ceramah kecuali apabila siswa menghendakinya, tidak menilai atau mengkritik pekerjaan murid kecuali apabila siswa memintanya.

Dalam bukunya "Freedom to Learn", Robert, (1975) ia memperkenalkan beberapa prinsip-prinsip belajar humanistik yang sangat penting, di antaranya ialah: 1) Manusia itu memiliki kemampuan untuk belajar secara alami. 2) Belajar yang bermakna terjadi apabila subjek matter dirasakan peserta didik mempunyai relevansi dengan maksud-maksudya sendiri. 3) Belajar yang melibatkan suatu perubahan yang ada di dalam tanggapan mengenai dirinya, dianggap mengancam dan cenderung akan ditolaknya. 4) Pekerjaan-pekerjaan belajar yang dapat mengancam diri adalah sangat mudah untuk dirasakan dan mudah diasimilasikan apabila ancaman dari luar tersebut semakin kecil. 5) Apabila ancaman kepada diri peserta didik rendah, pengalaman bisa diperoleh dengan melakukan berbagai cara yang bermacam-macam dan terjadilah sebuah proses belajar. 6) Belajar yang berarti bisa di dapatkan peserta didik dengan melakukannya. 7) Belajar dapat diperlancar bilamana peserta didik dilibatkan langsung dalam proses pembelajaran dan ikut serta bertanggung jawab dalam proses belajar tersebut. 8) Belajar atas inisiatif diri sendiri yang melibatkan diri peserta didik seutuhnya, baik itu perasaan maupun segi kognitif, merupakan cara yang bisa memberikan hasil yang mendalam dan lestari. 9) Kepercayaan pada diri sendiri, kemerdekaan, kreatifitas akan lebih mudah untuk dicapai apabila peserta didik dibiasakan untuk mawas diri dan mengeritik dirinya sendiri serta penilaian diri dari orang lain. 10) Belajar yang sangat berperan secara sosial di dunia modern ini adalah belajar dari proses belajar yang terbuka (alam) dan terus menerus pada pengalaman sehingga menyatu ke dalam dirinya sendiri mengenai proses perubahan itu. 
Carl Rogers menyatakan bahwa peserta didik yang belajar hendaknya tidak ditekan, melainkan dibiarkan belajar bebas sesuai dengan karakteristiknya, peserta didik diharapkan bisa mengambil sebuah langkah sendiri dan berani bertanggung jawab atas langkah- langkah yang diambilnya sendiri. Dalam konteks tersebut, Rogers menyatakan ada lima hal yang penting dalam proses belajar humanistik, sebagai berikut: a) Hasrat untuk belajar: keinginan untuk belajar dikarenakan adanya dorongan rasa ingin tahu manusia yang terus menerus terhadap dunia sekelilingnya. Dalam proses memecahkan jawabannya, seorang individu mengalami kegiatan-kegiatan belajar. b) Belajar bermakna: seseorang yang beraktivitas akan selalu mempertimbangkan apakah aktivitas tersebut mempunyai makna bagi dirinya. Jika tidak, tentu tidak akan dilakukannya. c) Belajar tanpa hukuman merupakan belajar yang terlepas dari hukuman atau ancaman menghasilkan anak bebas untuk melakukan apa saja, dan mengadakan percobaan hingga menemukan sendiri suatu hal yang baru dalam dirinya. d) Belajar dengan daya usaha atau inisiatif sendiri: menunjukkan tingginya motivasi internal yang dimiliki.

Peserta didik yang banyak inisiatif, akan mampu untuk memandu dirinya sendiri, menentukan pilihannya sendiri dan berusaha mempertimbangkan sendiri hal yang baik bagi dirinya. e) Belajar dan perubahan: keadaan dunia terus berubah, karena itu peserta didik mampu belajar untuk dapat menghadapi serta menyesuaikan kondisi dan situasi yang terus berubah. Dengan begitu belajar yang hanya dalam kontek mengingat fenomena atau menghafal kejadian dianggap tidak cukup karena itu hanya sebatas mengetahui saja dari apa yang dipelajarinya.

\section{Arthur Combs}

Menurut Combs, perilaku yang keliru atau tidak baik terjadi karena tidak adanya kesediaan seseorang melakukan apa yang seharusnya dilakukan sebagai akibat dari adanya sesuatu yang lain, yang lebih menarik atau memuaskan. Misalkan guru mengeluh peserta didik tidak berminat belajar, sebenarnya hal itu karena peserta didik itu tidak berminat melakukan apa yang dikehendaki oleh guru. Kalau saja guru tersebut lalu mengadakan aktivitas- aktivitas yang lain, barangkali peserta didik akan berubah sikap dan reaksinya. Sesungguhnya para ahli psikologi humanistik melihat dua bagian belajar, yaitu diperolehnya informasi baru dan personalisasi informasi baru tersebut. Adalah keliru jika guru berpendapat bahwa peserta didik akan mudah belajar kalau bahan pelajaran disusun dengan rapi dan disampaikan dengan baik, sebab arti dan maknanya tidak melekat pada bahan pelajaran itu; peserta didik sendirilah yang mencerna dan menyerap arti dan makna bahan pelajaran tersebut ke dalam dirinya. Yang menjadi masalah dalam mengajar bukanlah bagaimana bahan pelajaran itu disampaikan, tetapi bagaimana membantu peserta didik memetik arti dan makna yang terkandung di dalam bahan pelajaran yang akan diajarkan tersebut, yakni apabila peserta dapat mengaitkan bahan pelajaran tersebut dengan hidup dan kehidupan mereka, guru boleh bersenang hati bahwa missinya telah berhasil.

Semakin jauh hal-hal yang terjadi di luar diri seseorang (dunia) dari pusat lingkaran-lingkaran (persepsi diri), semakin kurang pengaruhnya terhadap seseorang. Sebaliknya, semakin dekat hal-hal tersebut dengan pusat lingkaran, maka semakin besar pengaruhnya terhadap seseorang dalam berperilaku. Jadi jelaslah mengapa banyak hal yang dipelajari oleh peserta didik segera dilupakan, karena sedikit sekali kaitannya dengan dirinya dan lingkungan yang di alaminya.

\section{Pendidikan Agama Islam}

Menurut Moh Haitami Salim (2013: 28-30) Pendidikan agama adalah pendidikan yang materi bimbingan dan arahannya adalah ajaran agama yang ditunjukan agar manusia mempercayai dengan sepenuh hati akan adanya Tuhan, patuh dan tunduk melaksanakan perintah Nya dalam bentuk beribadah, dan berakhlak mulia. Pendidikan agama adalah pendidikan yang diarahkan untuk menumbuh kembangkan rasa intuisi keagamaan yang ada dalam diri seseorang kemudian melaksanakan ajaran-ajarannya dengan penuh ketundukan.Pendidikan agama juga dapat di artikan sebagai usaha sadar yang di lakukan secara terecana dan sistematik untuk mengembangkan potensi diri melalui proses pembelajaran, latihan keterampilan, bimbingan, dan keteladanan diri sendiri dan orang lain agar memiliki keyakinan, pengetahuan, keterampilan, keteladanan, dan kepribadian yang sesuai dengan ajaran agama Islam. Implikasi dari pengertian di atas adalah pendidikan agama Islam harus: (1) berdasarkan falsafah ajaran Islam; (2) menurut ajaran yang sesuai dengan ruang lingkup syariat Islam; (3) menggunakan metodologi yang selaras dengan ajaran Islam; (4) memiliki prinsip pendidikan sepanjang hayat.

Menurut Zuhairini, (2004:1) secara umum pendidikan merupakan bimbingan secara sadar oleh pendidik terhadap perkembangan jasmani dan rohani peserta didik menuju terbentuknya kepribadian yang utama. Karena itu, pendidikan dipandang sebagai salah satu aspek yang memiliki peranan pokok dalam membentuk peserta didik agar memiliki kepribadian yang utama. Hery dalam Islam, sekurang-kurangnya 
terdapat tiga istilah yang digunakan untuk menandai konsep pendidikan, yaitu tarbiyah, ta`lim, dan ta`dib. Namun istilah yang sekarang berkembang di dunia Arab adalah tarbiyah.3 Istilah tarbiyah berakar pada tiga kata, raba-yarbu yang berarti bertambah dan tumbuh, yang kedua rabiya-yarba yang berarti tumbuh dan berkembang, yang ketiga rabba-yarubbu yang berarti memperbaiki, menguasai, memimpin, menjaga, dan memelihara. Kata al-rabb juga berasal dari kata tarbiyah dan berarti mengantarkan pada sesuatu kesempurnaannya secara bertahap atau membuat sesuatu menjadi sempurna secara berangsur-angsur.

Pendidikan secara harfiah berarti membimbing, memperbaiki, menguasai, memimpin, menjaga, dan memelihara. Esensi dari pendidikan adalah adanya proses transfer nilai, pengetahuan, dan keterampilan dari generasi tua kepada generasi muda agar generasi muda mampu hidup dan beradaptasi dengan lingkungannya. Karena itu, ketika kita menyebut pendidikan agama Islam, maka akan mencakup dua hal, yaitu: a) Mendidik peserta didik untuk berperilaku sesuai dengan nilai-nilai atau akhlak Islam b) Mendidik peserta didik untuk mempelajari materi ajaran agama Islam. Sedangkan pengertian pendidikan jika ditinjau secara definitive telah diartikan atau dikemukakan oleh para ahli dalam rumusan yang beraneka ragam, diantaranya Tayar Yusuf mengartikan Pendidikan Agama Islam sebagai usaha sadar generasi tua untuk mengalihkan pengalaman, pengetahuan, kecakapan, dan keterampilan kepada generasi muda agar menjadi manusia bertakwa kepada Allah. Zuhairini (2004: 1)) Pendidikan Agama Islam adalah usaha sadar untuk membimbing ke arah pembentukan kepribadian peserta didik secara sistematis dan pragmatis, supaya hidup sesuai dengan ajaran Islam, sehingga terjadinya kebahagiaan dunia akhirat.

Muhaimin (2001: 75-76) yang mengutip GBPP PAI, bahwa Pendidikan Agama Islam adalah usaha sadar untuk menyiapkan peserta didik dalam menyakini, memahami, menghayati, mengamalkan ajaran Islam melalui kegiatan, bimbingan, pengajaran dan latihan dengan memperhatikan tuntutan untuk menghormati agama lain dalam hubungan kerukunan antar umat beragama dalam masyarakat untuk mewujudkan persatuan nasional. Dengan demikian, maka pengertian Pendidikan Agama Islam berdasarkan rumusan-rumusan di atas adalah pembentukan perubahan sikap dan tingkah laku sesuai dengan petunjuk ajaran agama Islam. Sebagaimana yang pernah dilakukan Nabi dalam usaha menyampaikan seruan agama dengan berdakwah, menyampaikan ajaran, memberi contoh, melatih keterampilan berbuat, memberi motivasi dan menciptakan lingkungan sosial yang mendukung pelaksanaan ide pembentukan pribadi muslim. Untuk itu perlu adanya usaha, kegiatan, cara, alat, dan lingkungan hidup yang menunjang keberhasilannya.

Dari beberapa definisi di atas diambil unsur yang merupakan karakteristik Pendidikan Agama Islam: a) Pendidikan Agama Islam merupakan bimbingan, latihan, pengajaran, secara sadar yang diberikan pendidik terhadap peserta didik. b) Proses pemberian bimbingan dilaksanakan seseorang secara sistematis, kontiniu dan berjalan setahap demi setahap sesuai dengan perkembangan kematangan peserta didik. c) Tujuan pemberian agar kelak seseorang berpola hidup yang dijiwai oleh nilai-nilai Islam. d) Dalam pelaksanaan pemberian bimbingan tidak terlepas dari pengawasan sebagai proses evaluasi. Depdiknas Dasar, lanjutan Pertama dan Menenggah (2004: 18) Dalam kontek pembelajaran Pendidikan Agama Islam, Materi Pendidikan Agama Islam pada sekolah atau madrasah dasar lanjutan tingkat pertama dan lanjutan atas merupakan integral dari program pengajaran setiap jenjang pendidikan. Sesuai dengan tujuan pendidikan Nasional, Pendidikan Agama Islam diarahkan untuk membentuk manusia Indonesia seutuhnya.

Materi pokok Pendidikan Agama Islam dapat diklasifikasikan menjadi lima aspek kajian, yaitu: a) Aspek Al-Qur'an dan Hadist, dalam aspek ini menjelaskan beberapa ayat dalam Al-Qur'an dan sekaligus juga menjelaskan beberapa hukum bacaannya yang terkait dengan ilmu tajwid dan juga menjelaskan beberapa hadist Nabi Muhammad Saw. b) Aspek keimanan dan aqidah Islam, dalam aspek ini menjelaskan berbagai konsep keimanan yang meliputi enam rukun iman dalam Islam. c) Aspek akhlak, dalam aspek ini menjelaskan berbagai sifat-sifat terpuji (akhlak karimah) yang harus diikuti dan sifat-sifat tercela yang harus dijauhi. d). Aspek hukum Islam atau Fiqih, dalam aspek ini menjelaskan berbagai konsep keagamaan yang terkait dengan masalah ibadah dan mu'amalah. e) Aspek tarikh Islam, dalam aspek ini menjelaskan sejarah perkembangan atau peradaban Islam yang bisa diambil manfaatnya untuk diterapkan di masa sekarang.

\section{Telaah Teori Humanistik Dalam Pendidikan Agama Islam}

Berdasarkan prinsip-prinsip pembelajaran berpradigma humatistik di atas, Mohammad (2018) maka dapat dirumuskan Pendidikan Agama Islam sesuai dengan materi/sub materi PAI di sekolah dan madarasah. Berikut ini tabel pembelajaran Pendidikan Agama Islam dengan menggunakan paradigma pembelajaran Humanistik, sebagai berikut:

Berdasarkan paparan di atas maka disimpulkan bahwa pembelajaran PAI dalam paradigma humanistik menyatakan bahwa Pendidik dalam hal guru PAI dituntut untuk dapat menggunakan media, strategi dan 
metode pembelajaran, inovatif, aktif, kreatif dan menyenangkan sesuai dengan karakteristik peserta didik berdasarkan jenjang dan tingkatan pendidikannya. Pembelajaran Aktif dimaksudkan bahwa dalam proses pembelajaran, guru PAI diharapkan mampu menciptakan suasana belajar sedemikian rupa sehingga peserta didik aktif bertanya, mempertanyakan, dan mengemukakan ide dan gagasan. Misalnya dalam materi pembelajaran Fiqh, guru PAI memberikan kesempatan dan rangsangan agar peserta didik bertanya, mempertanyakan mengapa dan untuk apa disyariatkan sholat, puasa, zakat dan Haji. Sehingga diharapkan mampu mengembangkan cara belajar kreatif dalam pembelajaran Pendidikan Agama Islam tersebut.

Tabel 1. Integrasi Pembelajaran Kreatif dalam PAI

\begin{tabular}{ll}
\hline \multicolumn{1}{c}{ Materi Pembelajaran } & Pembahasan \\
\hline Akidah & Menjelaskan aspek keimanan sesuai dengan alam pikiran karakteristik \\
& peserta didik. \\
& Menampilkan bukti-bukti rasional keberadaan Alah, keesaan Allah, \\
& dan sifat-sifatnya Allah yang lain sesuai dengan karakteristik peserta \\
& didik. \\
& Menjelaskan kehadiran sifat-sifatnya Allah yang Maha pengasih dan \\
& maha penyayang, serta maha pemurah dan Maha Pemaaf sesuai \\
& dengan pengalaman peserta didik. \\
& Menampilkan dan mengutamakan ayat-ayat yang memberikan kabar \\
& gembira (bashiran) ayat-ayat yang menjanjikan surga dan kehidupan \\
& yang baik dan bahagia dunia dan diakhirat bagi orang-orang yang \\
& beriman dan beramal shaleh sesuai dengan karakteristik peserta didik. \\
Al Qur'an dan Hadist & Menampilkan dan mendahulukan ayat-ayat yang menjelaskan \\
& ketinggian derajat manusia khususnya orang beriman, \\
& Menampilkan dan mendahulukan ayat dan hadis yang mengajarkan \\
& asal kejadian manusia, kewajiban dan tanggung jawab manusia
\end{tabular}

Fiqih

Akhlak/ Tasauf

Sejarah Peradaban Islam
Menampilkan aturan dalam hukum Islam yang kontekstual dan tidak kaku (rigid). Menampilkan hukum Islam yang menjamin keadilan sosial Menampilkan hukum Islam yang menghormati keberagamaan/perbedaan pendapat

Menampilan ajaran-ajaran Akhlak yang mulia seperti kedermawan, solidaritas sosial, menghormati orang tua, guru, dan orang yang lebih tua.

Menjelaskan pentingnya dan manfaat akhlak yang mulia dalam kehidupan bersama.

Menjelaskan ajaran akhlak yang mementingkan toleransi (tasamuh), moderat (tawasuth) dan seimbang (tawazun).

Menampilkan ajaran tasawwuf yang bersanding dengan budaya, seni dan local wisdom.

Menampilkan ajaran tasawwuf untuk bersyukur kepada Allah dan berkewajiban seorang muslim untuk menjaga/ alam semesta sebagai wujud syukur kepada-Nya.

Menampilkan sejarah umat Islam yang mampu hidup berdampingan dengan toleransi yang tinggi dengan umat lain (masyarakat madani) pada masa Nabi Muhammad SAW dan Masa Khulafaurrasidin. Menjelaskan sejarah Islam dalam penyebaran Islam dengan damai keseluruh dunia melalui alkuturasi dan kontektualisasi ajaran Islam. Menjelaskan kemajuan umat Islam yang ditandai dengan penguasaan terhadap ilmu pengetahuan, penghormatan yang tinggi pada tradisi ilmiah dan perbedaan pendapat.

Pembelajaran kreatif adalah suatu bentuk pembelajaran yang menstimulasi peserta didik untuk mengembangkan gagasannya dengan memanfaatkan sumber belajar yang ada. Pembelajaran kreatif menekankan pada pengembangan kreatifitas, baik pengembangan kemampuan imajinasi maupun pengembangan kemampuan berpikir kreatif. Pembelajaran kreatif dalam PAI, misalnya guru PAI 
membimbing peserta didik untuk memahami konsep-konsep dalam hukum Islam dalam konteks perkembangan ilmu dan teknologi dan perubahan di masyarakat, membimbing peserta didik untuk memahami konsep-konsep akhlak dan tasawwuf, seperti zuhud, wara' dalam konteks kehidupan modern sesuai dengan perubahan dan perkembangan zaman sekarang. Sementara itu, Pembelajaran yang menyenangkan (joyful) adalah pembelajaran yang dapat dinikmati peserta didik. Peserta didik merasa nyaman, aman dan asyik. Perasaan yang mengasyikkan mengandung unsur inner motivation, yaitu dorongan keingintahuan yang disertai upaya mencari tahu sesuatu yang belum diketahui atau memperdalam sesuatu yang sudah diketahui sebelumnya. Penggunaan strategi tesebut dimaksudkan agar peserta didik dapat terlibat aktif dalam proses pembelajaran PAI, sehingga pembelajaran PAI yang dilaksanakan tidak membosankan bahkan sebaliknya menyenangkan.

\section{SIMPULAN}

Teori humanistik sangat relevan dengan Pendidikan Agama Islam, karena teori ini selalu mendorong peningkatan kualitas diri manusia melalui penghargaannya terhadap potensi-potensi positif yang ada pada setiap manusia. Sesuai dengan fitrah manusia itu sendiri sebagai makhluk ciptaan tuhan yang potensi itu perlu untuk dikembangkan, seiring dengan perubahan dan tuntutan zaman.

\section{REFERENSI}

Agus Zaenul Fitri, (2013), Manajemen Kurikulum Pendidikan Islam, Bandung: Alvabeta

Baharuddin, M. M. (2009). Pendidikan Humanistik, Konsep, Teori dan Aplikasi Praktis dalam Dunia Pendidikan. Yogyakarta: AR-Ruzz Media.

Budi, Asri Ningsih, (2005) Belajar dan Pembelajaran. Jakarta: Rineka Cipta,

Eka, Nova Irawan, (2005) "Buku Pintar Pemikiran Tokoh-Tokoh Psikologi dari Klasik Sampai Modern,"(Yogyakarta: IRCiSoD)

Darnim, K. Sudarwan (2011). Psikologi Pendidikan; dalam Perspektif Baru. Bandung: CV. Alfabeta.

Dian Andayani dan Abdul Majid, (2004) Pendidikan Agama Islam Berbasis Kompetensi, (Bandung: Remaja Rosdakarya)

Depdiknas Jendral Direktorat Pendidika Dasar, Lanjutan Pertama Dan Menengah, (2004) Pedoman Khusus Pengembangan Silabus Berbasis Kompetensi Sekolah Menengah Pertama,(Jakarta)

Feist, Jess. (2009). Teori Kepribadian, (Jakarta: Penerbit Salemba Humanika)

Hanafy, M. S. (2014). Konsep Belajar dan Pembelajaran. Lentera Pendidikan, Vol. 17

Haryu. (2006). Aplikasi Psikologi Humanistik dalam Pendidikan di Indonesia.Tadrîs Volume 1.Nomor 1.

Iskandar. (2016). Implementasi Teori Hirarki Kebutuhan Abraham Maslow Terhadap Peningkatan Kinerja Pustakawan, Vol. 4 No. 1, Januari - Juni 2016.

Muhaimin, dkk, (2001) Paradigma Pendidikan Islam, Upaya Mengefektifkan Pendidikan Agama Islam di Sekolah, (Bandung: PT. Remaja Rosdakarya)

Moiriam W. Schustackk dan Howard S. Freidman, (2008) Keperibadian Teori Klasik dan RisetModern, (Jakarta: Erlangga)

Muhaimin.(2003). Wacana. Pengembangan Pendidikan Islam. Yogyakarta: Pustaka Pelajar.

Naquib , Muhammad, Attâs Al. (1988). Konsep Pendidikan dalam Islam. Bandung: Mizan

Ni nyoman Perni, Adi widya (2018). Jurnal Pendidikan Dasar, volume 3, no 1 oktober 2018. ISSN 25275445) http//e jurnal.ihdn.ac.id/index.php/AW

Nidawati. (2013). Belajar dalam Perspektif Psikologi dan Agama. Jurnal Pionir, Volume 1, Nomor 1, JuliDesember.

Ningrum Suprihati Jamil, (2013). Strategi Pembelajaran: Teori dan Aplikasi, (Yogyakarta: Ar-Media,)

Roberts, T.B.(1975). Four Psychologies Applied to Education: Freudian, Behavioral, Humanistic, Transpersonal. New York: Schenkman Pub. Co.

Salim, Haitami, Moh. (2013). Pendidikan Agama Dalam Keluarga, Jogjakarta: Ar-Ruzz Media

Santrock, W, Jhon. (2009) Psikologi Pendidikan, (Jakarta: Salemba Humanika),

Subini, Nini, dkk. (2012). Psikologi pembelajaran. Yogyakarta: Mentari Pustaka. 